\title{
Sistem Pendukung Keputusan Pemberian Penghargaan UMKM Skala Mikro Di Kabupaten Bandung Barat Menggunakan Metode Analytic Hierarchy Process
}

\author{
Agung Wahyu Hadiana ${ }^{1}$, Wina Witanti ${ }^{2}$, Puspita Nurul Sabrina ${ }^{3}$ \\ ${ }^{1,2.3}$ Jurusan Informatika, Fakultas Sains dan Informatika, Universitas Jenderal Achmad Yani, Cimahi, Indonesia \\ e-mail: wahyu.hadiana@student.unjani.ac.id ${ }^{* 1}$,witanti@gmail.com², puspitasabrina14@gmail.com³
}

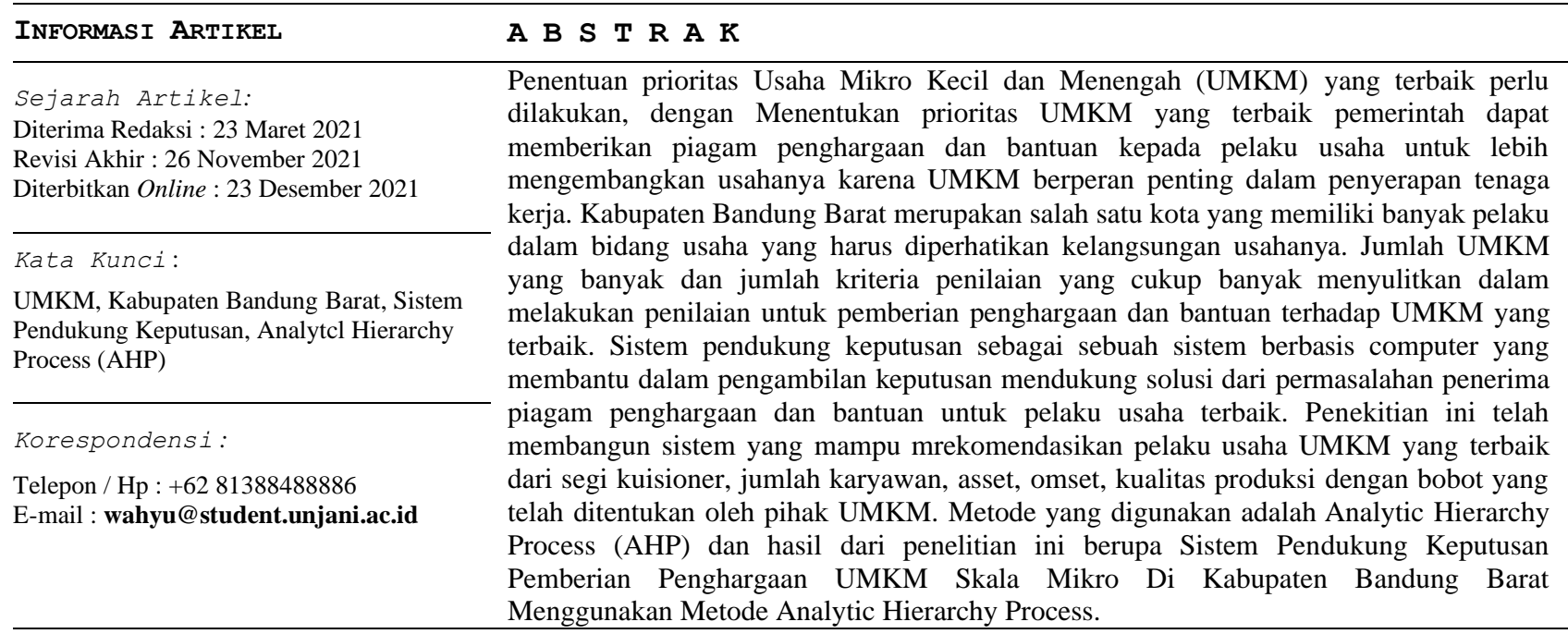

\section{PENDAHULUAN}

Usaha Kecil dan Menengah memainkan peran dan sistem penting untuk perputaran keuangan publik dan bisnis. Demikian pula, UMKM berperan dalam mengedarkan hasil kemajuan. Salah satu langkah penting dalam memperluas pembangunan. Merupakan satu langkah yang sangat strategis dalam meningkatkan dan memperkuat dasar perekonomian Indonesia salah satunya dengan mengembangkan dan memajukan UMKM. Usaha Mikro Kecil dan Menengah dapat menyediakan lapangan pekerjaan dan dapat mengurangi kesenjangan/tingkat kemiskinan yang ada diindonesia khususnya di Kabupaten Bandung Barat. Kabupaten Bandung Barat adalah sebuah kabupaten baru di provinsi Jawa Barat yang dibentuk tahun 2007 sebagai hasil pemekaran dari Kabupaten Bandung. Kabupaten Bandung Barat memiliki potensi alam dan potensi ekonomi yang memberikan kontribusi cukup besar terhadap perkembangan per-ekonomian daerah maupun nasional, sehingga memudahkan perkembangan dunia usaha, pertumbuhan usaha - usaha baru yang kreatif dan mempermudah untuk melakukan perkembangan ekonomi local terutama untuk usaha mikro dan kecil. Pemberian penghargaan dan bantuan dapat menjadi faktor yang mempengaruhi produktivitas dari pelaku usaha tersebut. UMKM yang memenuhi kriteria akan mendapatkan piagam penghargaan dan bantuan. Jumlah UMKM yang banyak dengan melibatkan kriteria yang cukup kompleks mempersulit pemberian penilaian kepada pelaku usaha terbaik sehingga tidak dapat dilakukan penilaian secara manual. Oleh karena itu bagaiamana membuat sistem pendukung keputusan yang dapat membantu UMKM dalam memberi keputusan pemberian penghargaan bagi UMKM terbaik di Kabupaten Bandung Barat. Piagam penghargaan dan bantuan ini diharapkan dapat memberi pengaruh baik terhadap pertumbuhan usaha di Kabupaten Bandung Barat dan menambah minat masyarakat untuk membuka peluang usaha baru.

Sistem Pendukung Keputusan telah umum digunakan oleh Instansi Pemerintah. Metode Analytical Hierarchy Process (AHP). Analytical Hierarchy Process digunakan untuk menentukan bobot dan kriteria yang telah ditentukan. Teknik ini pernah digunakan untuk membantu Badan Kepegawaian dan Pengembangan Sumber Daya Manusia kota Tangerang dalam menentukan layak atau tidaknya pegawai mendapatkan kenaikan pangkat [1]. Penelitian lain menunjukkan bahwa Analytical Hierarchy Process juga membantu dalam menentukan penilaian kinerja guru di SD Beji Unggaran dengan penilaian kuisioner[2]. Penelitian menunjukan informasi seberapa akuratnya untuk mengambil keputusan penentuan prioritas pelaku usaha terbaik dengan dibuatnya sebuah sistem yang dapat melakukan proses perankingan terhadap UMKM yang mengkuti perlombaan untuk menjadi UMKM terbaik di Kabupaten Bandung Barat. Data ini terdiri dari data UMKM dalam bidang kuliner, kerajinan dan bidang fashion. Data UMKM tersebut kemudian dimasukan kedalam sistem yang selanjutnya dilakukan proses penilaian untuk mendapatkan hasil berupa ranking pemenang piagam penghargaan dan bantuan, Sistem pendukung keputusan ini diharapkan dapat membantu 
pemerintah dalam memajukan Kabupaten Bandung Barat serta diharapkan dapat membuka lapangan kerja baru dan mengurangi pengangguran di Kabupaten Bandung Barat.

\section{METODE PENELITIAN}

Metode penelitian atau teknik pengujian berisi tahapan-tahapan yang berurutan, mulai dari perolehan informasi, analisis kebutuhan sistem, pengujian sistem saat ini, perencanaan sistem, eksekusi pemrograman, pengujian sistem.

\subsection{Perolehan Data}

Metode pengumpulan data atau pemilahan informasi adalah suatu prosedur atau teknik yang digunakan oleh pencipta untuk mengumpulkan informasi atau data. Bermacam-macam informasi diselesaikan untuk memperoleh data yang diperlukan untuk mencapai tujuan eksplorasi. Pada tahap pengumpulan informasi akan diselesaikan dalam beberapa tahap sebagai berikut :

a. Wawancara (Interview)

Dengan melakukan wawancara yang dilakukan pada tanggal 09 maret 2020 di Dinas Koperasi, Usaha Mikro Kecil dan Menengah yang berlokasi di Kabupaten Bandung Barat dengan Narasumber yaitu Kepala Bidang Pengembangan Usaha Mikro Kecil dan Menengah Bapak Pujo Semedi, S.H mengenai pengelolaan UMKM di wilayah Kabupaten Bandung Barat. Dan juga melalui aplikasi WathsApp Massenger dengan Bapak Arip sebagai Staf UMKM.

b. Observasi (Pengamatan)

Metode observasi digunakan dalam penelitian ini dimana penulis melakukan pengamatan secara langsung. Penulis melakukan pengamatan ke beberapa tempat usaha yang berada di wilayah Kabupaten Bandung Barat secara acak antara tanggal 1 April 2020 hingga 30 September 2020 serta mencatat kegiatan yang berlangsung.

c. Studi Pustaka

Studi Pustaka dilakukan untuk mengumpulkan informasi dari penelitian sebelumnya yang relevan dengan sistem pendukung keputusan serta mengevaluasi kembali untuk kemudian dipakai sebagai referensi dari penelitian ini.

\subsection{Pengembangan Perangkat Lunak}

Proses pengembangan perangkat lunak terdiri dari beberapa tahap yaitu tahap pra proses, tahap pengelompokkan menggunakan K-Medoids, dan tahap pengujian. Perancangan sistem dilihat pada Gambar 1.

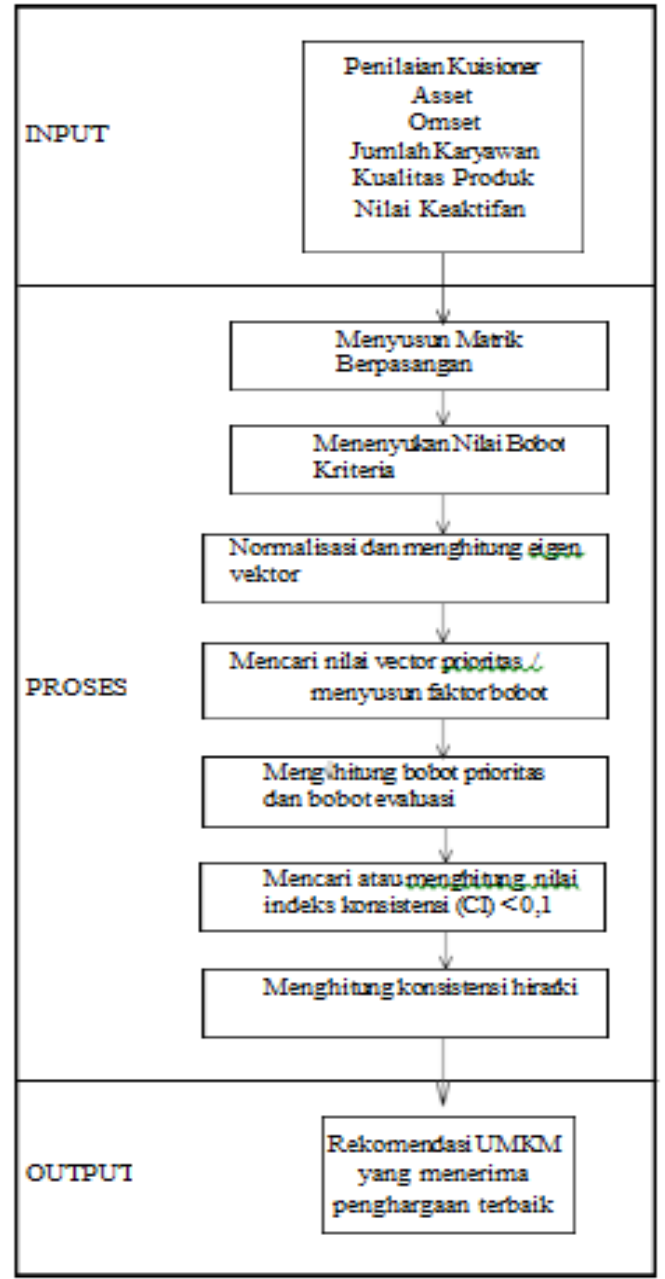

Gambar 1. Tahapan Metodologi Penelitian

\section{a. Tahapan Sistem Pendukung Keputusan}

Pada proses pengambilan keputusan diawali dengan mengidentifikasi atribut atau kriteria yang digunakan, dan terdapat 6 atribut atau kriteria yang dijadikan acuan oleh pihak Dinas UMKM dalam pengambilan keputusan :

1. Penilaian Kuisioner

2. Asset

3. Omset

4. Jumlah Karyawan

5. Kualitas Produksi

6. Nilai Keaktifan

\section{b. Tahap Pembobotan Dan Perankingan Mengguanakn Metode Analytic Hierarchy Process}

Pada bagian ini melakukan pencarian bobot pada atribut dengan menggunakan metode Analytical Hierarchy Process (AHP). Ada beberapa proses yaitu :

1. Menentukan kriteria - kriteria untuk menentukan UMKM terbaik

2. Menentukan kepentingan setiap kriteria

3. Menghasilkan nilai alternatif setiap kriteria

4. Mengubah kebentuk matrik perbandingan

5. Membuat matrik terbobot 
6. Membuat matrik ternormalisasi

7. Membuat matrik ternormalisasi terbobot

8. Menghitung konsistensi hirarki.

\section{c. Pengujian}

Pada tahap ini dilakukan pengujian pada setiap fungsi yang terdapat pada modul, hal ini dilakukan untuk mendeteksi apakah terdapat kesalahan pada sistem yang telah dibuat.

\section{TINJAUAN PUSTAKA}

Berikut penjelasan mengenai konsep pendukung yang digunakan dalam penelitian. Konsep yang akan dijelaskan dalam bab ini meliputi penelitian sebelumnya yang berkaitan dengan sistem pendukung keputusan, UMKM dan metode AHP.

\subsection{Sistem Pendukung Keputusan}

Sistem pendukung keputusan (SPK) berawal dari Sistem Informasi Manajemen (SIM) tradisional, karena menekankan pada fungsi mendukung pembuatan keputusan pada seluruh tahapannya. Sistem pendukung keputusan (SPK) yaitu bagian dari sistem informasi yang berbasis komputer kemudian dipakai untuk mendukung pengambilan keputusan dalam suatu organisasi, lembaga atau perusahaan. [3].

Beberapa definisi mengenai Sistem Pendukung Keputusan (SPK) adalah sebagai berikut[3,4]:

1. Sistem pendukung keputusan (SPK) merupakan sebuah sistem yang berbasis komputer dengan antarmuka antara mesin/komputer dan pengguna.

2. Sistem pendukung keputusan (SPK) memiki tujuan untuk membantu membuat keputusan dalam menyelesaikan masalah dalam berbagai level manajemen dan bukan untuk mengganti posisi manusia sebagai pembuat keputusan.

3. Sistem pendukung keputusan (SPK) memberikan alternatif solusi untuk masalah semi/tidak terstruktur baik bagi perorangan atau kelompok.

\subsection{Metode Analytic Hierarchy Process}

Metode Analytic Hierarchy Process (AHP) merupakan metode untuk mencari ranking atau dari berbagai alternatif dalam memecahkan suatu masalah. Dalam kehidupan sehari-hari, sering kali dihadapkan dalam menentukan pilihan alternatif ysng ada. Dalam penentuan pilihan diperlukan prioritas dan uji konsistensi terhadap pilihan-pilihan yang akan dikerjakan. Pengambilan keputusan dapat dipengaruhi oleh beberapa faktor yang memiliki kepentingan yang berbeda-beda $[4,5,6]$.

Dalam menyelesaikan masalah dengan metode AHP ada prinsip dasar yang harus anda pahami yaitu[4, $5,6]$ :

1. Decomposition, yaitu memecahkan suatu problema menjadi unsur-unsur ke dalam bentuk hirarki proses pengambilan suatu keputusan, dimana setiap unsur atau sebuah elemen saling berhubungan. Bentuk struktur dekomposisi yakni :

a. Tingkatan kesatu : Tujuan Keputusan

b. Tingkatan kedua : Kriteria-kriteria

c. Tingkatan ketiga : Alternatif-alternatif

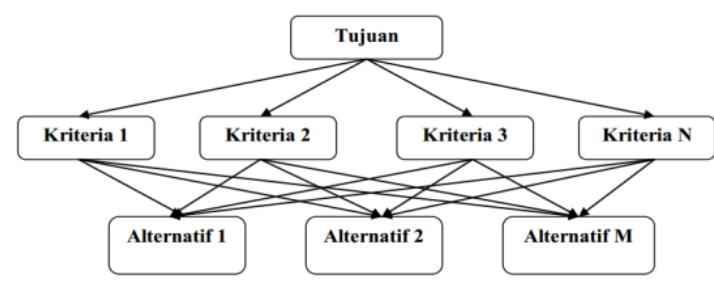

Gambar 2. Struktur Hirarki

2. Comparative Judgement, dilakukan dengan hal-hal yang mengidentifikasi dengan komponen pada suatu hal tentang tingkat di dalam dengan tingkat di atasnya. Penilaian ini menjadi inti dari AHP karena mempengaruhi permintaan kebutuhan komponen-komponennya. Efek lanjutan dari evaluasi ini lebih efektif diperkenalkan sebagai kerangka korelasi berpasangan, khususnya kisi pengujian dengan tingkat kecenderungan beberapa pilihan untuk setiap basis. Skala kemiringan yang digunakan adalah ukuran 1 yang menunjukkan tingkat paling minimal (ekuivalen signifikansi) hingga ukuran 9 yang menunjukkan tingkat paling tinggi (vital).

3. Synthesis of Priority, yaitu dengan menggunakan sebuah eigen vector method untuk menentukan bobot relatif yang berguna bagi pengambilan keputusan.

4. Logical Consistency, merupakan atribut penting dari AHP. Ini dicapai dengan mengumpulkan semua vektor eigen yang didapat dari tingkat yang berbeda dan kemudian memperoleh suksesi vektor komposit yang menghasilkan pengaturan dinamis.

Nilai numerik dikenakan bagi seluruh perbandingan diperoleh dari skala 1 sampai 9 yang telah ditetapkan oleh Saaty, dapat dilihat pada Gambar

\begin{tabular}{|c|l|l|}
\hline $\begin{array}{c}\text { Tingkat } \\
\text { Kepentingan }\end{array}$ & Definisi & Keterangan \\
\hline 1 & $\begin{array}{l}\text { Sama } \\
\text { penting }\end{array}$ & Kedua elemen mempunyai pengaruh yang sama \\
\hline 3 & $\begin{array}{l}\text { Sedikit } \\
\text { lebih } \\
\text { penting }\end{array}$ & $\begin{array}{l}\text { Pengalaman dan penilaian sangat memihak satu } \\
\text { elemen dibandingkan dengan pasangannya }\end{array}$ \\
\hline 5 & $\begin{array}{l}\text { Lebih } \\
\text { penting }\end{array}$ & $\begin{array}{l}\text { Satu elemen sangat disukai dan secara praktis } \\
\text { dominasinya sangat nyata, dibandingkan dengan } \\
\text { elemen pasangannya }\end{array}$ \\
\hline 7 & $\begin{array}{l}\text { Sangat } \\
\text { penting }\end{array}$ & $\begin{array}{l}\text { Sau elemen terbukti sangat disukai dan secara praktis } \\
\text { dominasinya sangat, dibandingkan dengan elemen } \\
\text { pasangannya }\end{array}$ \\
\hline 9 & $\begin{array}{l}\text { Mutlak } \\
\text { lebih } \\
\text { penting }\end{array}$ & $\begin{array}{l}\text { Satu elemen mutlak lebih disukai dibandingkan } \\
\text { dengan pasangannya, pada tingkat keyakinan } \\
\text { tertinggi }\end{array}$ \\
\hline Resiprokal & $\begin{array}{l}\text { Kebalikan } \\
\text { tengah }\end{array}$ & $\begin{array}{l}\text { Nika elemen I memiliki salah satu angka diantara dua pilihan yang berdekatan } \\
\text { dibandingkan elemen j, maka elemen } \mathrm{j} \text { memiliki } \\
\text { kebalikannya ketika disbanding elemen i }\end{array}$ \\
\hline
\end{tabular}

Gambar 3. Skala Saaty 
Menentukan bobot / eigen vector terdapat beberapa langkah-langkah seperti berikut:

1. Menghitung normalisasi matriks

Pada tahap ini, terdapat 2 (dua) langkah yaitu menjumlahkan tiap kolom dan tiap cell dari kolom dibagi berdasarkan jumlah tiap kolom.

2. Menghitung eigen vector / bobot

a. Menghitung eigen value

Menghitung nilai eigen value merupakan perkalian dari setiap baris dipangkatkan dengan 1 dibagi n, seperti pada persamaan berikut:

Eigen Value $=(\operatorname{am} 1 * a m 2 * \ldots * a m n)^{\wedge}(1 / n)$

Kemudian Jumlah Eigen merupakan penjumlahan dari semua nilai Eigen Value.

Jumlah Eigen $=\sum$ Eigen Value

b. Menghitung bobot prioritas

Bobot prioritas untuk kriteria ke-i dapat diperoleh dengan membagi nilai bi dengan nilai c, seperti pada persamaan berikut:

Bobot Prioritas $=($ Eigen Value $) /($ Jumlah Eigen $)$.....(2.3)

c. Menghitung bobot sintesa

Bobot sintesa didapatkan dari matriks yang telah dinormalisasi dan menjumlahkan setiap barisnya seperti pada persamaan berikut :

Bobot Sintesa $=\sum$ aij.

3. Menghitung nilai eigen maksimum ( $\lambda$ maks)

Nilai eigen maksimum adalah parameter AHP yang begitu penting untuk digunakan sebagai rujukan menghitung rasio konsistensi (Consistency Ratio) .

Pengecekan matriks konsisten atau tidak konsisten yaitu diawali dengan membagi bobot sintesa dengan bobot prioritas.

Cek Matriks $=($ Bobot Sintesa $) /($ Bobot Prioritas $) \ldots . .(2.5)$

Kemudian hasil dari pembagian tersebut dijumlahkan untuk mendapatkan nilai $\mathrm{x}$.

$\mathrm{X}=\sum$ Cek Matriks

Hitung nilai eigen maksimum ( $\lambda$ maks), yaitu $x$ dibagi dengan jumlah kriteria.

$\lambda$ maks $=\mathrm{x} /$ (orde matriks $)$..

4. Uji Indeks begitu juga Rasio

Salah satu model utama AHP yang membedakannya dari model dinamis lainnya adalah bahwa tidak ada prasyarat konsistensi yang mutlak. Bermacam-macam penilaian antara satu komponen dengan komponen lainnya bebas satu sama lain, dan hal ini dapat menimbulkan jawaban yang saling bertentangan yang diberikan oleh responden. Namun, banyak penyimpangan juga mengganggu. Mengulangi wawancara dengan jumlah responden yang sama ada di sana-sini yang mendasar jika konsistensinya sangat besar $[4,5,6]$.

Saaty telah membuktikan bahwa Indeks Konsistensi dari matriks berordo $\mathrm{n}$ dapat diperoleh dengan rumus[8,9]:

$$
\mathrm{CI}=((\lambda \max -\mathrm{n})) /((\mathrm{n}-1)) \text {. }
$$

$\mathrm{CI}=$ Rasio penyimpangan (deviasi) konsistensi (consistency index)

$\Lambda \max =$ Nilai eigen terbesar dari matriks berordo $\mathrm{n}$ $\mathrm{N}=$ Orde matriks
Jika CI adalah nol, kisi pemeriksaan pasangan berwawasan konsisten. Penyimpangan terjauh yang telah ditetapkan oleh Thomas L. Masih mengudara menggunakan Consistency Ratio (CR), yaitu pemeriksaan file konsistensi dengan nilai rekor tidak teratur (RI) yang diperoleh dari penyelidikan oleh Oak Ridge National Laboratorium dan selanjutnya dibuat oleh Wharton School dan ditampilkan seperti Tabel 2.3. Ini bernilai tergantung pada jaringan permintaan $n$. Dengan demikian, Rasio Konsistensi dapat dihitung sebagai berikut: $[4,5,6]$ :

CR= CI/RI ..........................................(2.9)
CR
RI rasio konsistensi
\begin{tabular}{|l|l|l|l|l|l|l|l|l|} 
R indeks random \\
$\mathrm{N}$ & 1 & 2 & 3 & 4 & 5 & 6 & 7 & 8 \\
\hline $\mathrm{RI}$ & 0.00 & 0.00 & 0.58 & 0.90 & 1.12 & 1.24 & 1.32 & 1.41 \\
\hline
\end{tabular}

\begin{tabular}{|l|l|l|l|l|l|l|l|}
\hline $\mathrm{N}$ & 9 & 10 & 11 & 12 & 13 & 14 & 15 \\
\hline $\mathrm{RI}$ & 1.45 & 1.49 & 1.51 & 1.48 & 1.56 & 1.57 & 1.59 \\
\hline
\end{tabular}

Gambar 4. Indeks Random

\subsection{Usaha Mikro, Kecil Dan Menengah}

UMKM adalah usaha yang dimiliki oleh orangorang yang memenuhi standar. UMKM mewakili Usaha Mikro, Kecil dan Menengah. Ukuran untuk setiap bisnis adalah usaha mini, kecil dan menengah [7].

a. Usaha Mikro

Usaha mikro sebagaimana dimaksud dalam UU no. 20 Tahun 2008 tentang UMKM adalah usaha bermanfaat yang dimiliki oleh orang yang memenuhi ketentuan untuk usaha mini dengan jumlah kekayaan paling banyak Rp. 50.000.000 (Lima Puluh Juta Rupiah) pembatasan area dan struktur untuk tempat usaha atau memiliki kesepakatan tahunan untuk semua hal yang dianggap Rp. 300.000.000 (Tiga Ratus Juta Rupiah)[7].

b. Usaha Kecil

Usaha Kecil seperti yang ditunjukkan oleh UU no. 20 Tahun 2008, Usaha Kecil adalah usaha keuangan yang bermanfaat yang bersifat soliter, yang dilakukan oleh orang perseorangan atau unsur usaha yang nyatanyata bukan merupakan pembantu atau bagian dari suatu organisasi yang diklaim, atau menjadi bagian baik secara langsung maupun melalui perantara. atau bisnis besar yang memenuhi standar bisnis. kecil. Memiliki total aset lebih dari Rp. 50.000.000 area dan struktur pembatasan untuk tempat usaha, atau memiliki penawaran tahunan lebih dari Rp. 300.000 .000 sampai dengan Rp. 2.500.000.000 [7].

c. Usaha Menengah

Sebagaimana dimaksud dalam Undang-Undang Nomor 20 Tahun 2008, usaha menengah adalah usaha keuangan yang bermanfaat yang bersifat soliter, yang dilakukan oleh orang atau tidak dimiliki oleh bagianbagian organisasi, atau menjadi bagian baik secara langsung maupun akibat dengan perusahaan swasta atau 
perusahaan besar. organisasi. Memiliki total aset lebih dari Rp. 500.000.000 sampai dengan Rp. 10.000.000.000 area dan struktur pembatasan untuk tempat usaha, atau memiliki penawaran tahunan lebih dari Rp. 2.500.000.000 sampai dengan Rp. $10,000,000,000$ [7].

\section{HASIL DAN PEMBAHASAN}

Pada penelitian ini akan dibangun Sistem Pendukung Keputusan Pemberian Penghargaan UMKM Skala Mikro Menggunakan Metode Analytical Hierarchy Process.

\subsection{Identifikasi Data UMKM}

Pada penelitian ini penulis mengidentifikasi kriteria untuk menentukan UMKM mana yang lebih di prioritaskan untuk menerima piagam penghargaan dan bantuan dari Pemerintah Daerah agar dapat meningkatkan kinerja dan usahanya lebih maksimal, serta membagi alternatif yang mana akan memilih usaha apa yang akan dilihat untuk mendapatkan piagam penghargaan dan bantuan tersebut.

Kriteria UMKM Penerima Piagam Penghargaan Penyusunan kriteria dalam menentukan UMKM mana yang akan menjadi prioritas penerima piagam penghargaan dan bantuan dalam penelitian ini terdapat pada Tabel 3.8.

\begin{tabular}{|c|}
\hline KRITERIA \\
\hline Kuisioner maksimal nilai 100 \\
\hline Jumlah karyawan maksimal 10 orang \\
\hline Aset maksimal 50 Juta Rupiah \\
\hline Omzet maksimal 300 Juta Rupiah \\
\hline Kualitas Produksi (Standar, Bagus, Sangat Bagus) \\
\hline Nilai Keaktifan maksimal 100 \\
\hline
\end{tabular}

Gambar 5. Kriterian Penerima Bantuan

\subsection{Alternatif Penerima Bantuan}

Alternatif yang digunakan untuk menjadi bahan penilaian UMKM adalah sektor/bidang yang terdaftar di Dinas Koperasi, Usaha Kecil dan Menengah Kabupaten Bandung Barat terdapat pada Ttabel 3.9

\begin{tabular}{|c|}
\hline ALTERNATIF (SEKTOR USAHA) \\
\hline Kuliner \\
\hline Fashion \\
\hline Perdagangan \\
\hline
\end{tabular}

Gambar 6. Sektor Usaha Penerima Piagam Penghargaan

\subsection{Perhitungan Data Menggunakan AHP (Analytic Hierarchy Process)}

\subsubsection{Data awal}

Sample data awal UMKM Kabupaten Bandung Barat a. Indikator Lembaga

\begin{tabular}{|c|c|c|c|c|l|}
\hline $\begin{array}{c}\text { Nama } \\
\text { Usaha }\end{array}$ & $\begin{array}{c}\text { Nama } \\
\text { Pemilik/Ketua }\end{array}$ & $\begin{array}{c}\text { Komoditi, } \\
\text { jenis usaha }\end{array}$ & Kampung & Desa & Kecamatan \\
\hline TRINAZ & $\begin{array}{c}\text { Sri Tuti } \\
\text { Rahmawati }\end{array}$ & Cookies & $\begin{array}{c}\text { Perum Pur } \\
\text { Budi Asri } \\
\text { Blok Jno 5 }\end{array}$ & Cihanjuang & Parongpong \\
\hline Opak & Iis & Opak & Cihanjuang & Cihanjuang & Parongpong \\
\hline Kiripik & Ibar & Keripik & Cihanjuang & Cihanjuang & Parongpong \\
\hline $\begin{array}{c}\text { Pengolah } \\
\text { an Baso } \\
\text { Sehat }\end{array}$ & Irfan Permadi & Baso & $\begin{array}{c}\text { Jl. Cisintok } \\
\text { No.148 RT } \\
\text { 04/13 Desa }\end{array}$ & Cihanjuang & Parongpong \\
\hline
\end{tabular}

Gambar 7. Indikator Lembaga

Sumber: Dinas Koperasi, Usaha Kecil dan Menengah Kabupaten Bandung Barat

\begin{tabular}{|c|c|c|c|c|}
\hline Sektor Usaha & KTP & No. Tlpn/Hp & Email & $\begin{array}{c}\text { Tahun } \\
\text { Mulai } \\
\text { Usaha }\end{array}$ \\
\hline Kuliner & $\begin{array}{c}3217020101900 \\
001\end{array}$ & $\begin{array}{c}0226610884 / 0229 \\
1911958\end{array}$ & $\begin{array}{c}\text { Trinaz@gmail.co } \\
\underline{\underline{m}}\end{array}$ & 2015 \\
\hline Kuliner & $\begin{array}{c}3217020101900 \\
002\end{array}$ & 0226348249 & $\frac{\text { opakiis@gmail.co }}{\underline{\underline{m}}}$ & 2016 \\
\hline Kuliner & $\begin{array}{c}3217020101900 \\
003\end{array}$ & 02263485831 & $\frac{\text { kiripikibar@gmai }}{\underline{1 . \text { com }}}$ & 2015 \\
\hline Kuliner & $\begin{array}{c}3217020101900 \\
004\end{array}$ & 0226348234 & $\frac{\text { basosehat@gmail. }}{\underline{\text { com }}}$ & 2015 \\
\hline
\end{tabular}

Gambar 8. Indikator Lembaga

Sumber: Dinas Koperasi, Usaha Kecil dan Menengah Kabupaten Bandung Barat

b. Indikator Usaha

\begin{tabular}{|c|c|c|c|c|c|}
\hline \multicolumn{2}{|c|}{$\begin{array}{l}\text { Tenaga } \\
\text { Kerja }\end{array}$} & \multirow[t]{2}{*}{ Asset (Rp.000) } & \multirow{2}{*}{$\begin{array}{c}\text { Kapasitas } \\
\text { produksi/Minggu }\end{array}$} & \multirow{2}{*}{$\begin{array}{l}\text { Omzet / tahun } \\
\text { (Rp.000) }\end{array}$} & \multirow[t]{2}{*}{ Perijinan/sertifikart } \\
\hline $\mathbf{L}$ & $\mathbf{P}$ & & & & \\
\hline 1 & 2 & 45.000 .000 & $140 \mathrm{pcs}$ & 254.800 .000 & SIUM \\
\hline 1 & 1 & 20.000 .000 & 15 Ball & 78.000 .000 & SIUM \\
\hline 1 & 1 & 20.000 .000 & 15 Ball & 78.000 .000 & SIUM \\
\hline 3 & 2 & 20.000 .000 & 350 bakso & 273.000 .000 & SIUM \\
\hline
\end{tabular}

Gambar 9. Indikator Usaha

Sumber: Dinas Koperasi, Usaha Kecil dan Menengah Kabupaten Bandung Barat 


\begin{tabular}{|c|c|c|c|c|}
\hline NPWP & Pemasaran & $\begin{array}{c}\text { Kualitas } \\
\text { Produk }\end{array}$ & $\begin{array}{c}\text { Nilai } \\
\text { Keaktifan }\end{array}$ & Kuisioner \\
\hline Ada & $\begin{array}{c}\text { Bandung, } \\
\text { Cimahi }\end{array}$ & Bagus & 90 & 95 \\
\hline Ada & $\begin{array}{c}\text { Bandung, } \\
\text { Cimahi }\end{array}$ & Sangat Bagus & 100 & 100 \\
\hline Ada & $\begin{array}{c}\text { Bandung, } \\
\text { Cimahi }\end{array}$ & Bagus & 90 & 90 \\
\hline Ada & $\begin{array}{c}\text { Bandung, } \\
\text { Cimahi }\end{array}$ & Sangat Bagus & 80 & 100 \\
\hline
\end{tabular}

Gambar 10. Idnikator Usaha

Sumber: Dinas Koperasi, Usaha Kecil dan Menengah Kabupaten Bandung Barat

\subsubsection{Menentukan Tingkat Kepentingan}

Menentukan tingkat kepentingan dari kriteria kriteria yang ada

\begin{tabular}{|c|c|}
\hline Parameter & Tingkat Kepentingan \\
\hline Kuisioner & 9 \\
\hline Jumlah Karyawan & 7 \\
\hline Omset & 5 \\
\hline Asset & 3 \\
\hline Kualtias Produk & 2 \\
\hline Nilai Keaktifan & 4 \\
\hline
\end{tabular}

Gambar 11. Tingkat Kepentingan

\subsubsection{Perhitungan Matriks Perbandingan Berpasangan}

Pada penentuan matriks perbandingan berpasangan, penulis membagi semua kriteria dengan bobotnya masing masing sehingga menemukan hasil dari perbandingan berpasangan. Hasil dari perhitungan dapat dilihat pada Gambar

\begin{tabular}{|c|c|c|c|c|c|c|}
\hline $\mathbf{X}$ & Kuisioner & $\begin{array}{c}\text { Jumlah } \\
\text { Karyawan }\end{array}$ & Omset & Asset & $\begin{array}{c}\text { Kualtas } \\
\text { Produk }\end{array}$ & $\begin{array}{c}\text { Nilai } \\
\text { Keaktifan }\end{array}$ \\
\hline Kuisioner & 1 & $9 / 7$ & $9 / 4$ & $9 / 5$ & $9 / 3$ & $9 / 2$ \\
\hline $\begin{array}{c}\text { Jumlah } \\
\text { Karyawan }\end{array}$ & $7 / 9$ & 1 & $7 / 4$ & $7 / 5$ & $7 / 3$ & $7 / 2$ \\
\hline Omset & $4 / 9$ & $4 / 7$ & 1 & $4 / 5$ & $4 / 3$ & $4 / 2$ \\
\hline Asset & $5 / 9$ & $5 / 7$ & $5 / 4$ & 1 & $5 / 3$ & $5 / 2$ \\
\hline $\begin{array}{c}\text { Kualitas } \\
\text { Produk }\end{array}$ & $3 / 9$ & $3 / 7$ & $3 / 4$ & $3 / 5$ & 1 & $3 / 2$ \\
\hline $\begin{array}{c}\text { Nilai } \\
\text { Keaktifan }\end{array}$ & $2 / 9$ & $2 / 7$ & $2 / 4$ & $2 / 5$ & $2 / 3$ & 1 \\
\hline
\end{tabular}

Gambar 12 Perhitungan Matrik Kriterua

\begin{tabular}{|c|c|c|c|c|c|c|}
\hline $\mathbf{X}$ & Kuisioner & $\begin{array}{c}\text { Jumlah } \\
\text { Karyawan }\end{array}$ & Omset & Asset & $\begin{array}{c}\text { Kualtas } \\
\text { Produk }\end{array}$ & $\begin{array}{c}\text { Nilai } \\
\text { Keaktifan }\end{array}$ \\
\hline Kuisioner & 1 & 1.285714 & 2.25 & 1.8 & 3 & 4.5 \\
\hline $\begin{array}{c}\text { Jumlah } \\
\text { Karyawan }\end{array}$ & 0.777778 & 1 & 1.75 & 1.4 & 2.333333 & 3.5 \\
\hline Omset & 0.444444 & 0.571429 & 1 & 0.8 & 1.333333 & 2 \\
\hline Asset & 0.555556 & 0.714286 & 1.25 & 1 & 1.666667 & 2.5 \\
\hline $\begin{array}{c}\text { Kualitas } \\
\text { Produk }\end{array}$ & 0.333333 & 0.428571 & 0.75 & 0.6 & 1 & 1.5 \\
\hline $\begin{array}{c}\text { Nilai } \\
\text { Keaktifan }\end{array}$ & 0.222222 & 0.285714 & 0.5 & 0.4 & 0.666667 & 1 \\
\hline
\end{tabular}

Gambar 13. Perhitungan Tabel Kriterian

\subsubsection{Menjumlahkan Nilai Elemen}

Menjumlahkan nilai Esetiap kolom dari nilai-nilai elemen matriks kriteria diatas, maka jumlah elemen setiap kolom adalah

\begin{tabular}{|c|c|c|c|c|c|c|}
\hline $\mathbf{X}$ & Kuisioner & $\begin{array}{c}\text { Jumlah } \\
\text { Karyawan }\end{array}$ & Omset & Asset & $\begin{array}{c}\text { Kualtas } \\
\text { Produk }\end{array}$ & $\begin{array}{c}\text { Nilai } \\
\text { Keaktifan }\end{array}$ \\
\hline Kuisioner & 1 & 1.285714 & 2.25 & 1.8 & 3 & 4.5 \\
\hline $\begin{array}{c}\text { Jumlah } \\
\text { Karyawan }\end{array}$ & 0.777778 & 1 & 1.75 & 1.4 & 2.333333 & 3.5 \\
\hline Omset & 0.444444 & 0.571429 & 1 & 0.8 & 1.333333 & 2 \\
\hline Asset & 0.555556 & 0.714286 & 1.25 & 1 & 1.666667 & 2.5 \\
\hline $\begin{array}{c}\text { Kualitas } \\
\text { Produk }\end{array}$ & 0.333333 & 0.428571 & 0.75 & 0.6 & 1 & 1.5 \\
\hline $\begin{array}{c}\text { Nilai } \\
\text { Keaktifan }\end{array}$ & 0.222222 & 0.285714 & 0.5 & 0.4 & 0.666667 & 1 \\
\hline Jumlah & 3.333333 & 4.285714 & 7.5 & 6 & 10 & 15 \\
\hline
\end{tabular}

Gambar 14.Tabel Perjumlahan

\subsubsection{Menghitung Matriks Normalisasi}

Dengan memisahkan setiap komponen dalam segmen dengan jumlah segmen yang pas dari harga kisi komponen dan jumlah setiap bagian di atasnya, kerangka standarisasi dapat ditentukan dengan membagi setiap komponen dalam segmen dengan jumlah segmen yang tepat, yang dapat ditemukan pada Gambar 15..

\begin{tabular}{|c|c|c|c|c|c|c|}
\hline $\mathbf{X}$ & Kuisioner & $\begin{array}{c}\text { Jumlah } \\
\text { Karyawan }\end{array}$ & Omset & Asset & $\begin{array}{c}\text { Kualtas } \\
\text { Produk }\end{array}$ & $\begin{array}{c}\text { Nilai } \\
\text { Keaktifan }\end{array}$ \\
\hline Kuisioner & 0.3 & 0.3 & 0.3 & 0.3 & 0.3 & 0.3 \\
\hline $\begin{array}{c}\text { Jumlah } \\
\text { Karyawan }\end{array}$ & 0.233333 & 0.233333 & 0.233333 & 0.233333 & 0.233333 & 0.233333 \\
\hline Omset & 0.133333 & 0.133333 & 0.133333 & 0.133333 & 0.133333 & 0.133333 \\
\hline Asset & 0.166667 & 0.166667 & 0.166667 & 0.166667 & 0.166667 & 0.166667 \\
\hline $\begin{array}{c}\text { Kualitas } \\
\text { Produk }\end{array}$ & 0.1 & 0.1 & 0.1 & 0.1 & 0.1 & 0.1 \\
\hline $\begin{array}{c}\text { Nilai } \\
\text { Keaktifan }\end{array}$ & 0.066667 & 0.066667 & 0.066667 & 0.066667 & 0.066667 & 0.066667 \\
\hline
\end{tabular}

Gambar 15. Normalisasi Matriks

\subsubsection{Penjumlahan Matriks}

Setelah kerangka standarisasi diperoleh, tahap selanjutnya adalah memasukkan setiap lini dalam segmen dalam organisasi. Kuantitas setiap bagian pada 


Gambar
\begin{tabular}{|c|c|c|c|c|c|c|c|}
\hline $\mathbf{X}$ & Kuisioner & $\begin{array}{c}\text { Jumlah } \\
\text { Karyawan }\end{array}$ & Omset & Asset & $\begin{array}{c}\text { Kualtas } \\
\text { Produk }\end{array}$ & $\begin{array}{c}\text { Nilai } \\
\text { Keaktifan }\end{array}$ & Jumlah \\
\hline Kuisioner & 0.3 & 0.3 & 0.3 & 0.3 & 0.3 & 0.3 & 1.8 \\
\hline $\begin{array}{c}\text { Jumlah } \\
\text { Karyawan }\end{array}$ & 0.233333 & 0.233333 & 0.233333 & 0.233333 & 0.233333 & 0.233333 & 1.4 \\
\hline Omset & 0.133333 & 0.133333 & 0.133333 & 0.133333 & 0.133333 & 0.133333 & 0.8 \\
\hline Asset & 0.166667 & 0.166667 & 0.166667 & 0.166667 & 0.166667 & 0.166667 & 1 \\
\hline $\begin{array}{c}\text { Kualitas } \\
\text { Produk }\end{array}$ & 0.1 & 0.1 & 0.1 & 0.1 & 0.1 & 0.1 & 0.6 \\
\hline $\begin{array}{c}\text { Nilai } \\
\text { Keaktifan }\end{array}$ & 0.066667 & 0.066667 & 0.066667 & 0.066667 & 0.066667 & 0.066667 & 0.4 \\
\hline
\end{tabular}

Gambar 16. Penjumalahan Matriks

Setelah mendapatkan bilangan pada setiap kolom, nilai kebutuhan ukuran ditentukan dengan membagi setiap komponen dengan besaran aturan $(\mathrm{n}=$ 6) sehingga kebutuhan dapat ditentukan sebagai berikut.

Prioritas Kuisioner : $1.8 / 6=0,3$

Prioritas Jumlah Karyawan : $1.4 / 6=0,233333$

Prioritas Asset : 0.8/6 =0,133333

Prioritas Omset : $1 / 6=0,166667$

Prioritas Nilai Kualitas Produk : 0.6/6 = 0,1

Prioritas Nilai Keaktifan : 0.4/6 $=0.066667$

Sehingga jika dalam bentuk tabel dapat dilihat pada Gambar 17.

\begin{tabular}{|c|c|}
\hline Kriteria & Rata - Rata \\
\hline Kuisioner & 0.3 \\
\hline Jumlah Karyawan & 0.233333 \\
\hline Asset & 0.133333 \\
\hline Omset & 0.166667 \\
\hline Kualitas Produk & 0.1 \\
\hline Nilai Keaktifan & 0.066667 \\
\hline JUMLAH & 1 \\
\hline
\end{tabular}

Gambar 17. Nilai Rata - Rata Kriteria

Untuk menghitung konsistensi index penulis menggunakan rumus

$(\mathrm{CI})=(\lambda$ maks-n $) /(\mathrm{n}-1)$

Sehingga Nilai CI dapat dihitung dengan cara sebagai berikut

$(\mathrm{CI})=(5,950972-6) /(6-1)=-0,00981$

Menghitung rasio konsistensi dengan rumus

$(\mathrm{CR})=\mathrm{CI} / \mathrm{RI}$

RI adalah Random Index dengan nilai 1,12 karena pada kasus ini mempunyai ukuran matriks 5, sehingga nilai darai CR dapat di hitung dengan cara sebagai berikut $(\mathrm{CR})=(-0,00981) / 1,24=-0,00791$

Karena nilai Rasio Konsistensinya adalah $-0,00791 \leq$ 0,1, maka matriks diatas bisa dikatakan konsisten.

\subsubsection{Pengujian Konsistensi}

Untuk pengujuan konsistensi, penulis akan membuat matriks berpasangan menggunakan 6 kriteria sebelumnya yang sudah dihitung dengan 3 alternatif yaitu UMKM 1, UMKM 2 dan UMKM 3. Dengan skala saaty sebagai berikut :

Skala Saaty Kusisioner :

$$
\begin{aligned}
& 1=10 \operatorname{sd} 20 \\
& 3=21 \text { sd } 40 \\
& 5=41 \text { sd } 60 \\
& 7=61 \text { sd } 80 \\
& 9=81 \text { sd } 100
\end{aligned}
$$

Skala Saaty Jumlah Karyawan :

$$
\begin{aligned}
& 1=1 \text { sd } 2 \\
& 3=3 \text { sd } 4 \\
& 5=5 \text { sd } 6 \\
& 7=7 \text { sd } 8 \\
& 9=9 \text { sd } 10
\end{aligned}
$$

Skala Saaty Asset :

$$
\begin{aligned}
& 1=1 \text { juta }-10 \text { juta } \\
& 3=11 \text { juta } 20 \text { juta } \\
& 5=21 \text { juta }-30 \text { juta } \\
& 7=31 \text { jta }-40 \text { juta } \\
& 9=41 \text { juta }-50 \text { juta }
\end{aligned}
$$

Skala Saaty Omset :

$$
\begin{aligned}
& 1=1 \text { juta sd } 60 \text { juta } \\
& 3=61 \text { juta sd } 120 \text { juta } \\
& 5=121 \text { juta sd } 180 \text { juta } \\
& 7=181 \text { juta } s d 240 \text { juta } \\
& 9=241 \text { juta } \text { sd } 300 \text { juta }
\end{aligned}
$$

Skala Saaty Kualitas Produk :

$$
\begin{aligned}
& 3=\text { Standar } \\
& 5=\text { Bagus } \\
& 7=\text { Sangat Bagus }
\end{aligned}
$$

Skala Saaty Nilai Keaktifan ;

$$
\begin{aligned}
& 1=10 \text { sd } 20 \\
& 3=21 \text { sd } 40 \\
& 5=41 \text { sd } 60 \\
& 7=61 \text { sd } 80 \\
& 9=81 \text { sd } 100
\end{aligned}
$$

Table 3. 15 Matriks Alternatif UMKM

\begin{tabular}{|c|c|c|c|c|c|c|}
\hline $\mathbf{X}$ & Kuisioner & JK & Asset & Omset & KP & NKf \\
\hline $\begin{array}{c}\text { UMKM } \\
\mathbf{1}\end{array}$ & 70 & 3 & 20 Juta & 100 Juta & Standar & 70 \\
\hline $\begin{array}{c}\text { UMKM } \\
\mathbf{2}\end{array}$ & 80 & 5 & 30 Juta & 150 Juta & Bagus & 80 \\
\hline $\begin{array}{c}\text { UMKM } \\
\mathbf{3}\end{array}$ & 100 & 9 & 40 Juta & 250 Juta & $\begin{array}{c}\text { Sangat } \\
\text { Bagus }\end{array}$ & 100 \\
\hline
\end{tabular}

Gambar 18. Matriks Alternatif UMKM

$\mathrm{JK}=$ Jumlah Karyawan

$\mathrm{KP}=$ Kualitas Produk

NK $=$ Nilai Keaktifan

Perhitungan akan menggunakan Mircrosoft Excel supaya memudahkan penulis dalam melakukan perhitungan alternatif - alternatif yang sudah ditentukan.

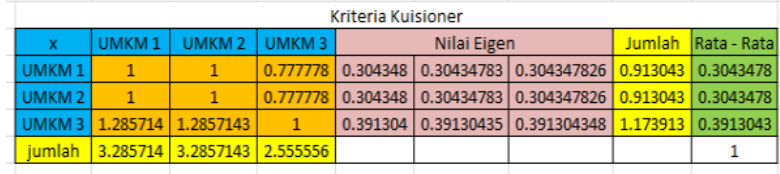

Gambar 19. Tabel Hasik Perhitungan Kriteria Kuisioner 


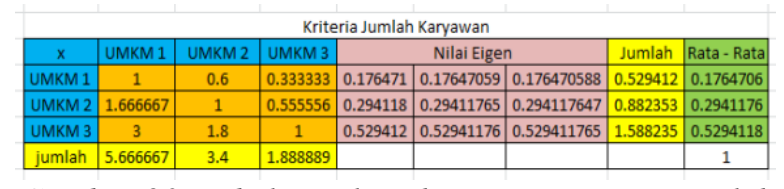

Gambar 20. Tabel Hasil Perhitungan Kriteria Jumlah Karyawan

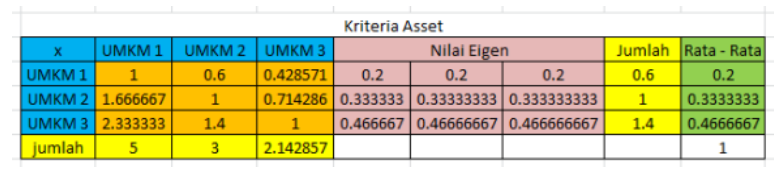

Gambar 3. 5 Tabel Hasil Perhitungan Kriteria Asset

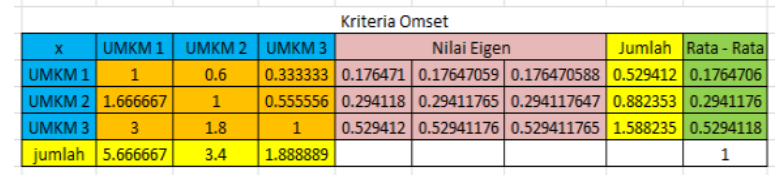

Gambar 3. 6 Tabel Hasil Perhitungan Kriteria Omset

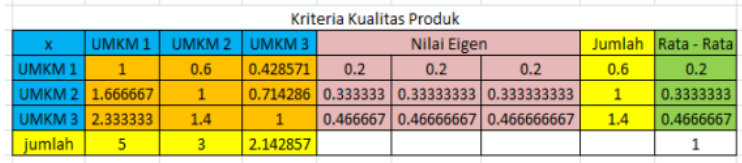

Gambar 21. Tabel Hasil Perhitungan Kriteria Kualitas Produk

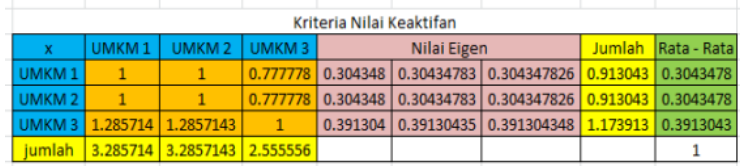

Gambar 22. Tabel Hasil Perhitungan Kriteria NIlai Keaktifan

\begin{tabular}{|c|c|c|}
\hline Perankingan & Hasil & Juara \\
\hline UMKM 1 & 0.229124 & 3 \\
\hline UMKM 2 & 0.306834 & 2 \\
\hline UMKM 3 & 0.464042 & 1 \\
\hline
\end{tabular}

Gambar 23. Hasil Rekomendasi UMKM Terbaik

Hasil dari pengujian konsistensi dapat dilihat bahwa yang mendapatkan piagam penghargaan dan bantuan juara 1 adalah UMKM 3, juara 2 UMKM 2 dan juara 3 yaitu UMKM 1.

\section{KESIMPULAN}

Setelah melakukan analisa perancangan, implementasi dan pengujian, sistem yang dibangun menggunakan metode Analytic Hierarchy Process (AHP) dengan data kriteria sebanyak 6 data diantaranya penilaian kuisioner, jumlah karyawan, asset, omset, Kualitas Produk, dan nilai kekatifan. Berdasarkan hasil pengujian kualitas secara fungsional sistem pendukung keputusan pemberian penghargaan UMKM terbaik telah berjalan sesuai dengan perancangan yang telah dibuat.

Sistem pendukung keputusan penentuan UMKM terbaik di Kabupaten Bandung Barat ini dapat membantu pihak UMKM dalam penentuan pelaku usaha terbaik. Sistem pendukung keputusan merupakan sistem yang hanya dapat merekomendasikan saja untuk keputusan yang akan diambil dikembalikan kepada pengambil keputusan.

\section{DAFTAR PUSTAKA}

[1] R. A. Suherdi, R. Taufiq, and A. A. Permana, "Penerapan Metode AHP dalam Sistem Pendukung Keputusan Kenaikan Pangkat Pegawai Di Badan Kepegawaian Dan Pengembagan Sumber Daya Manusia Kota Tangerang," Sintak, pp. 522-528, 2018.

[2] S. Rakasiwi, "Sistem Pendukung Keputusan Dalam Menentukan Penilaian Kinerja Guru Dengan Metode Analytical Hierarchy Process (Ahp)," Simetris J. Tek. Mesin, Elektro dan Ilmu Komput., vol. 9, no. 2, pp. 1001-1008, 2018, doi: 10.24176/simet.v9i2.2528.

[3] JYaqin, A. (2016). Sistem Pendukung Keputusan Kelayakan Pemberian Bidikmisi Dengan Fuzzy Logic. Cogito Smart Journal, 2(1).

[4] N. Palasara, "Sistem Pengambilan Keputusan Pemilihan Karyawan Terbaik Menggunakan Metode Analytic Hierarchy Process," vol. 4, no. 1, pp. 31-46, 2017.

[5] Darmanto, E., Latifah, N., \& Susanti, N. (2014). Penerapan Metode Ahp (Analythic Hierarchy Process) Untuk Menentukan Kualitas Gula Tumbu. Simetris : Jurnal Teknik Mesin, Elektro Dan Ilmu Komputer, 5(1), 75. https://doi.org/10.24176/simet.v5i1.13 9

[6] Parhusip, F., Yustika, A., Syahputri, I., Damanik, N. S., \& Solikhun. (2018). SPK : Analisa Metode AHP Pada Guru Berprestasi di SD 095130 Senio Bangun. 3(1), 1-5.

[7] Y. R. Suci, S. Tinggi, and I. Ekonomi, "Perkembangan UMKM (Usaha Mikro Kecil Menengah) di Indonesia," J. Ilm. Fak. Ekon., vol. 6, no. 1, pp. 51-58, 2017 ..

[8] D. P. Sari, O. M. Febriani, and A. S. Putra, "Perancangan Sistem Informasi SDM Berprestasi pada SD Global Surya,” pp. 289-294, 2018.

[9] S. Sundari et al., "Sistem Pendukung Keputusan Dengan Menggunakan Metode Electre Dalam Merekomendasikan Dosen Berprestasi Bidang Ilmu Komputer ( Study Kasus di AMIK \& STIKOM Tunas Bangsa )," no. x, 2012..

[10] S. R. Siregar, "SISTEM PENDUKUNG KEPUTUSAN PEMBERIAN KREDIT PNS DENGAN METODE AHP DAN TOPSIS ( Studi Kasus : PT . Bank Sumut Cabang Binjai )," vol. 2, no. 1, pp. 35-45, 2018.

[11] A. N. Process, "Analysis of the Difficulties of SMEs in Industry 4.0 Applications by Analytical Hierarchy Process and Analytical Network Process „, 2018, doi: 10.3390/pr6120264. 